\title{
A Profile Analysis of Scientific Thinking Ability of XI Grade Senior High School Students in Pacitan Regency
}

\author{
$1^{\text {st }}$ Seto Prio Asmoro \\ Biology Education, Postgraduate of \\ Science Education Program \\ Sebelas Maret University (UNS) \\ Surakarta, Indonesia \\ asmoro320@gmail.com
}

\author{
$2^{\text {nd }}$ Suciati \\ Biology Education, Postgraduate of \\ Science Education Program \\ Sebelas Maret University (UNS) \\ Surakarta, Indonesia \\ asmoro320@gmail.com
}

\author{
$3^{\text {rd }}$ Baskoro Adi Prayitno \\ Biology Education, Postgraduate of \\ Science Education Program \\ Sebelas Maret University (UNS) \\ Surakarta, Indonesia \\ asmoro320@gmail.com
}

\begin{abstract}
This study is aimed to analyse scientific thinking abilities profile of science students at XI Grade of Senior High School in Pacitan Regency, East Java Province. The population of this study was 664 students. The sample was taken by using cluster random sampling method on 68 students of SMAN 1 Pacitan, SMAN 1 Ngadirojo, and SMAN Tulakan. The instrument used was a test instrument in the form of multiple choice questions of 25 items which were developed based on the aspects of scientific thinking ability, they are inquiry, analysis, inferences, and argumentation (Kuhn, 2010). Data were analysed using descriptive quantitative statistics. Based on data analysis, it is obtained that the percentage of students with post formal category of scientific thinking ability is $0 \%$, the upper formal category is $\mathbf{2 7 . 9 4 \%}$, the low formal category is $67.64 \%$, and the concrete category is $4.42 \%$. Based on the results of data analysis, it shows that the profile of scientific thinking ability of science students at XI Grade of Senior High School in Pacitan Regency is still relatively low so that a process of learning activity that can empower students' scientific thinking ability is needed.
\end{abstract}

Keywords—analysis; scientific thinking ability; Pacitan

\section{INTRODUCTION}

One of the indicators of the progress of a nation is the development of human resources that can be realized through the role of education. As stated in the Republic of Indonesia Law number 20 in 2003 concerning of the national education system; education is a conscious and planned effort to create a learning atmosphere and learning process in order to make students actively develop their potential to have religious spiritual strength, self-control, personality, intelligence, noble character, and skills needed by themselves, society, nation, and state. In its implementation, education is directly contributed to the progress of all area of science, such as science education. One of the expectations to be achieved in science education learning in high school based on the 2013 curriculum is students have the ability to think scientifically
(Permendikbud 2016: 24). This is in accordance with the statement of Koerber (2015) who stated that the development of scientific thinking ability is more focused on the general understanding of the characteristics of science. Scientific thinking in the dynamic development of natural science in complex education field is needed as the basis of thinking which is related to the students' needs to solve problems in everyday life.

The realm of scientific thinking is related to how to observe, record, describe, question, form of explanation, and finally draw a conclusion (Lackaff, 2013). This is in line with Kuhn (2010) who stated that scientific thinking is the exploration of knowledge which includes examples of any thought that is intended, in which the aim is to improve the knowledge of those who seek it. This definition is then followed by a description of scientific thinking stages which consist of inquiry, analysis, inference, and argument. The inquiry phase is an important part which the purpose of the activity is made, the inquiry phase contains the process of composing the purpose of activity, identification of data and initial phenomena, connecting the findings of the phenomenon to the initial knowledge of the students, and the process of formulating the problem. The analysis phase is the product analysis that covers the process of taking, processing, interpreting, and displaying data obtained from the previous phase. The inference phase is a conclusion stage that produces a product from previous activities. This phase includes the process of compiling data and empirical evidence into a theory, the exploration of other factors that can influence results, the coordination between facts and theories, and the process of taking final conclusions appropriately. Argument phase is the final stage which is expected that the process of delivering an opinion is in line with the facts and theories, delivering of variety of results, submission of an objection to the proposed theories, and the process of maintaining the consistency of submitted statement (Kuhn, 2010). The 
importance of scientific thinking in the education field is in contrary to the habits that should be avoided by students. Students are more convinced by the approach they are willing to do to solve a problem and more often ignore the unpleasant aspects of the data (Kleinman in hendrich 2018: 9).

Scientific thinking is not only an approach to solve problems, a higher scientific thinking ability can give a positive impact on students' learning outcomes. High scientific thinking ability influences students' high cognitive learning outcomes (Cavallo, et.al: 2003). Besides, according to Dunbar \& Fugelslang (2005) scientific thinking is a process that involves students' cognitive ability in building the knowledge. Considering the importance of the ability to think scientifically in learning, teachers should organize scientific thinking abilities in their learning process.

In fact, a learning process that accommodates scientific thinking abilities such as inquiry-based learning is still considered as an unclear concept to most teachers and educational researchers in Indonesia (Farida, 2017). The meaning of inquiry learning has not been understood and the benefits have not been recognized, therefore the implementation of inquiry learning does not create any improvement of the quality of science education in Indonesia (Rustaman, 2005). Another opinion mentioned that students interpret scientific thought as something that happened in the lab, not as something that has value in everyday life such as decision-making or solving a problem (Hendrich, 2018).

The same case happened in SMAN Pacitan. Based on the results of the observation done in SMAN 1 Pacitan, SMAN 1 Ngadirojo, and SMAN Tulakan, the teachers did not empower the ability to think scientifically in the process of learning. The learning process was still centred on the teacher and had not accommodated the scientific thinking ability. Students were more demanded to listen and memorize in the learning process, thus students tended to be passive and were not accustomed to think scientifically in learning. After teachers and students were interviewed, it was obtained that teachers were not used to apply learning models that could facilitate scientific thinking abilities. The teachers had not applied learning that is oriented to the process of science. The result of interviewing students shows that students are not familiar to implement a learning that is oriented on aspects of scientific thinking. Students feel that the learning process is teachercentred, it is rarely to do practical activities. Based on the background of the problem, it is necessary to do a research on An Analysis of Profile of Scientific Thinking Ability of XI Grade of Senior High School's in Pacitan Regency.

\section{METHODS}

This research was implemented in Pacitan Regency consisting of 3 State of Senior High Schools. The population of this research was all of science students at the XI grade of senior high school in Pacitan Regency in the academic year 2017/2018, which amount is 664 students with 68 students as the samples. 17 students from eleventh science class at SMAN 1 Pacitan, 27 students from eleventh science class at SMAN 1 Ngadirojo, and 24 students from eleventh science class at SMAN Tulakan. The technique of sampling used cluster random sampling which taking the samples in the same group (cluster), so that each object is considered to have the same opportunity (Sugiyono, 2015).

The technique of data collection used observation, interview, and test of scientific thinking ability. The test instrument of students' scientific thinking ability is 25 questions in the form of multiple choice questions which consist of scientific thinking ability aspects, namely: 1) inquiry; 2) analysis; 3) inference; and 4) argument (Kuhn, 2010). The item test of scientific thinking ability used in this study has been validated both internally and externally. Observation is made using an observation sheet. An interview was carried out using interview guidelines. Test's result of scientific thinking ability then classified into 4 categories of scientific thinking ability levels, namely: 1) Post Formal; 2) Upper Formal ; 3) Low Formal;4) Concrete, with criteria as in table 1 .

Table 1. Table of Levels of Scientific Thinking Ability

\begin{tabular}{cc}
\hline Score & Level of Scientific Thinking Ability \\
\hline $20-25$ & Post Formal \\
$15-19$ & Upper Formal \\
$10-14$ & Low Formal \\
$0-9$ & Concrete \\
\hline
\end{tabular}

( Lawson in Wijayadi 2017: 154 ).

The calculation of the percentage score of the aspect of scientific thinking abilities on every level of scientific thinking ability is as follows:

Percentage Score $=\frac{\text { total score }}{\text { maximum score }} \times 100 \%$

This is a descriptive research with quantitative approach. Descriptive research is a research that analyses its data by describing the data as it is without intending to make general conclusion or generalization. Research with a quantitative approach is a research that its analysis focuses on numerical data processed using a statistical technique (Sugiyono, 2015).

\section{RESULT AND DISCUSSION}

\section{A. The Reult of Reaserch}

Table 2 . Description of Scientific Thinking Ability

\begin{tabular}{ccc}
\hline Score & Percentage & $\begin{array}{c}\text { Level of Scientific } \\
\text { Thinking Ability }\end{array}$ \\
\hline $20-25$ & 0 & Post Formal \\
$15-19$ & 27.94 & Upper Formal \\
$10-14$ & 67.64 & Low Formal \\
$0-9$ & 4.42 & Concrete \\
\hline
\end{tabular}

Based on table 2, the result of the test shows that the level of scientific thinking ability is $4.42 \%$ of students categorized as concrete level, the higher percentage is $67.64 \%$ who is categorized as low formal level, while the rest is $27.94 \%$ who is categorized as upper formal level, and there are no students in the category of post formal level. 


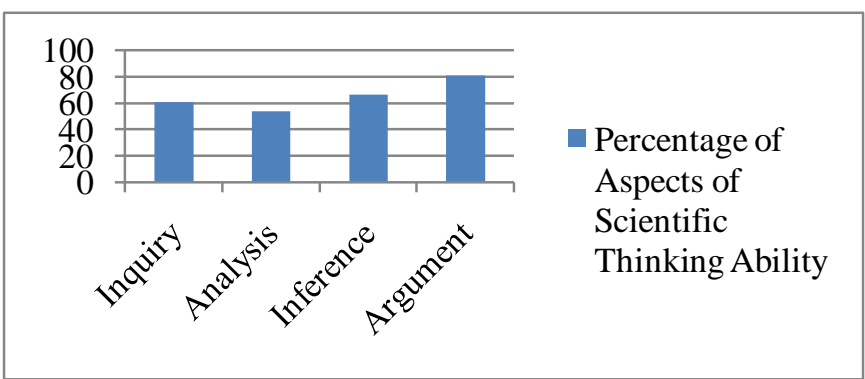

Figure 1. Percentage of Aspects of Scientific Thinking Ability on Upper Formal category

Figure 1 shows that the aspect of student's inquiry on upper formal category in scientific thinking is $60.53 \%$, aspect of analysis is $53.51 \%$, aspect of inference is $66.45 \%$ and aspect of argument $80.7 \%$.

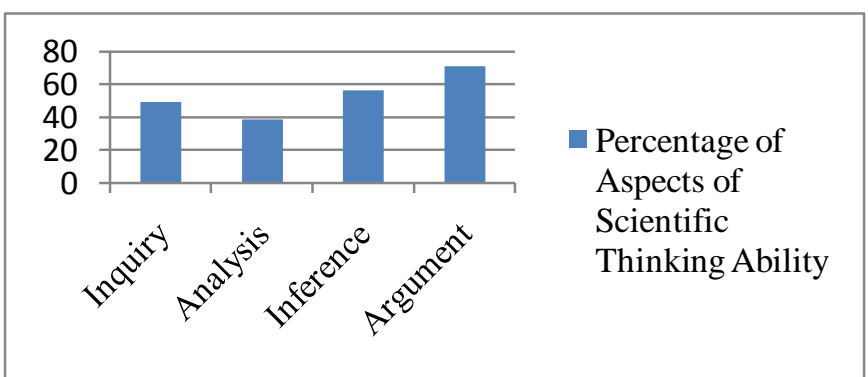

Figure 2. Percentage of Aspects of Scientific Thinking Ability on Low Formal category

Figure 2 shows that the aspect of student's inquiry on low formal category in scientific thinking is $48.91 \%$, aspect of analysis is $38.41 \%$, aspecti if inferenc is $55.98 \%$, and aspect of argument is $71.01 \%$.

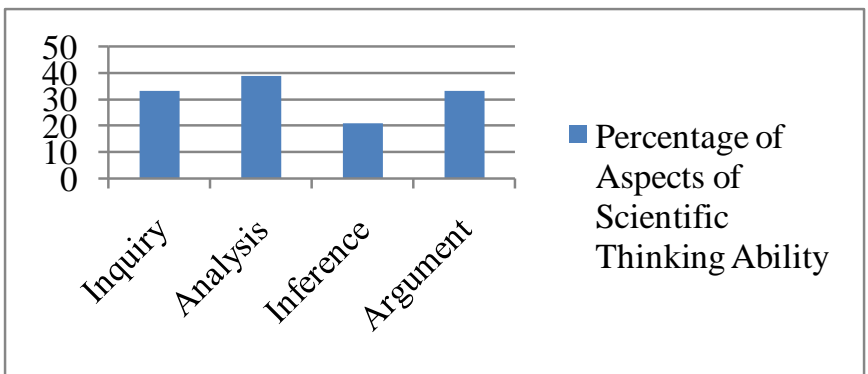

Figure 3. Percentage of Aspects of Scientific Thinking Ability on Concrete category

Figure 3 shows that the aspect of student's inquiry on concrete category ins cientific thinking is $33.33 \%$, aspects of analysis is $38.89 \%$, aspect of inference is $20.83 \%$ and aspect of argument is $33.33 \%$.

\section{B. Discussion}

Begin with a phenomenon of lack of scientific thinking ability empowerment, this research was conducted which aim is to analyse the profile of scientific thinking ability. Based on the results of the study, Figure 1 and Figure 2 show that aspect of analysis on upper formal and low formal categories are in the lowest percentage of other aspects of scientific thinking ability. In the analysis aspect, students obtain the information through the identification process of the inquiry aspect. In the aspect of analysis, students also compare the previous knowledge with the results of identification. Aspect of analysis consists of four indicators that contain the process of taking, processing, interpreting, and displaying data (Kuhn, 2010). The low percentage of analysis aspects can be meant that students are not optimally conditioned in the process of taking, processing, interpreting, and displaying data.

In addition to aspect of analysis on concrete category of scientific thinking ability based on figure 3 , it is obtained that aspect of inference is also in the lowest percentage of aspects of scientific thinking ability. In the aspect of inference, students analysed the data of investigation results which was obtained from inquiry aspect and analysis aspect, which then was continued to conclude the results of the activity. Inference aspect consists of four indicators they are; 1) the process of compiling data and empirical evidence into a theory; 2) exploration of other factors that can affect results; 3 ) coordination between facts and theories; 4) the process of drawing final conclusion (Kuhn, 2010). Percentage of low inference aspect indicated that students still had not mastered a process that included the compiling of data and empirical evidence into a theory, the exploration of other factors that can influence results, coordination between facts and theories, and the process of drawing final conclusions.

It is equally important, the inquiry aspect as an aspect of initiating the ability to think scientifically based on Figures 1, 2 and 3 is not an aspect that has the lowest percentage, but the percentage still needs to be improved considering the inquiry is an important part which the purpose of the activity is made (Kuhn, 2010 ). The process of compiling the objective of the activity, identification data and initial phenomenon, linking the findings of the phenomenon with prior knowledge of the students, and the process of formulating the problems are the contents of inquiry aspect which are greatly affected the objectivity of the data and determination of purpose.

Based on Figures 1, 2 and 3, argument aspects in scientific thinking ability also do not occupy the lowest percentage, but this aspect still needs to be improved because argument aspect is the final phase in which is expected that the process of delivering opinion is in accordance with facts and theories, delivering of variety of results, submission of an objection to the proposed theories, and the process of maintaining the consistency of submitted statement (Kuhn, 2010).

The categorization of the level of scientific thinking ability in table 2 shows that $67.64 \%$ of students are in the low formal category, and $4.42 \%$ in the concrete category. This defines that $72.06 \%$ of students are in a low level of scientific thinking ability. The rest is $27.94 \%$ of students are in the upper formal category, and there are no students in the post formal category. The low ability to think scientifically can be caused by several reasons. Unutkan (2006) stated that scientific thinking ability is affected by the level of education, a higher level of education will result in the higher ability of students to think scientifically. Kahn, et al. (2016) stated that parents with a high education level have a greater influence on children to do a good learning process in their studies at the secondary school level. This certainly affects the students' scientific 
thinking ability that is in line with idea of Galton's, et al. (2009) who stated that the classroom environment has an important effect on the ability to think scientifically, the classroom environment referred refers to the learning process in the classroom. One of the components that are needed in the learning process is a learning tool. The preparation of learning tools is a part of the learning plan (Permendikbud No. 65 in 2013 concerning Standard for Basic and Secondary Education Processes). The learning plan is designed in the form of syllabus and Rencana Pelaksanaan Pembelajaran (RPP).

In this study, it is obtained that $72.06 \%$ of students are in a low level of scientific thinking ability. Furthermore, $27.94 \%$ are students in the upper formal category, and there are no students in the post formal category. One of the ways to improve scientific thinking ability is through the learning tools that facilitate the ability to think scientifically.

\section{CONCLUSION AND SUGGESTION}

\section{A. Conclusion}

Based on the results and discussion of the research, it can be concluded that $72.06 \%$ of students are in a low level of scientific thinking ability. In the learning process, the teacher does not empower scientific thinking ability. The learning process is still teacher-centred style and the learning does not accommodate scientific thinking ability. Students are more demanded to listen and memorize in learning, so students tend to be passive and do not accustomed to think scientifically in learning. The teachers have not been accustomed to use learning models that can facilitate students' scientific thinking ability. The teachers still have not applied the learning that is oriented to the science process. Students are not familiar to implement the learning process that is oriented to aspects of scientific thinking. Students feel that the learning process is still teacher-centred and is rarely to do some practical activities.

\section{B. Suggestion}

Teachers should use learning models that are oriented to the scientific process to facilitate students' scientific thinking ability. The learning models that can be used are inquiry learning model, discovery learning model, Project Based Learning (PBL) model, and other learning models that facilitate students in conducting an investigation. One of the learning components is Rencana Pelaksanaan Pembelajaran (RPP), it also must accommodate the ability to think scientifically so that learning aspects of scientific thinking abilities can be trained directly to students.

Researchers should conduct further research on the scientific thinking abilities learning device. Researchers can also develop a research on scientific thinking abilities in different samples beside Pacitan regency.

\section{Acknowledgment}

Our gratitude is given to the supervisor of the Science Education Postgraduate Program, Majored in Biology Education, Sebelas Maret University, who has guided in the writing of this research article. We also say our gratitude to the principals of SMAN 1 Pacitan, SMAN 1 Ngadirojo, and
SMAN Tulakan who have given permission to conduct research, and students who have worked together in collecting research data. And thank you to colleagues who have helped in conducting research activities.

\section{References}

Cavallo, A. M. L., Rozman, M., Blickenstaff, J., \&Walker, N. (2003). Learning, reasoning, motivation, and epistemological beliefs.Journal of College Science Teaching. 33: 18-23.

Dunbar, K. N. \&Fugelslang, J. A. (2005).Brain-Based Mechanisms Underlying Complex Causal Thinking.Journal of Neuropshy. 43: 1204-1213.

Farida, Ika A, dkk. 2017. Developing Scientific Thinking Through Inquiry Learning. Advances in Social Science, Education and Humanities Research.Atlantis Press.

Galton, M., Hargreaves, L. \& Pell, T. (2009). Group Work and Whole-Class Teaching with 11- to 14-Year-Olds Compared. Cambridge Journal of Education. 39(1): 119-140.

Hendrich, Suzanne, dkk. 2018. Development of Scientific Thinking Facilitated by Reflective Self-Assessment in a Communication-Intensive Food Science and Human Nutrition Course. Journal of Food Science Education. Vol. 17 (1): 8-13.

Khan, R. M. A., Nadeem, I., \&Saina, T. (2016).The influence of Parents Educational level on Secondary School Students Academic achievements in District Rajanpur.Journal of Education and Practice. 6(6): 7679.

Kuhn, Deanna. 2010. What is Scientific Thinking and How Does it Develop?.Handbook of Childhood Cognitive Development. $2^{\text {nd }}$ ed. New York: Columbia University.

Lackaff, Julie dan Hoisington, Cynthia. 2013. Scientific Thinking Background and Criteria. Scientific Thinking Research Summary for The Work Sampling System. $5^{\text {th }}$ ed. USA: Pearson Education, Inc.

Permendikbud No 34.2016. Kompetensi Inti dan Kompetensi Dasar Pelajaran Pada Kurikulum 2013 Pada Pendidikan Dasar dan Pendidikan Menengah. Jakarta: Menteri Pendidikan dan Kebudayaan Republik Indonesia.

Permendikbud No 65. 2013. Standar Proses PendidikanDasardanMenengah. Jakarta: Menteri Pendidikan dan Kebudayaan Republik Indonesia.

Rustaman, Nuryani Y. 2005. Perkembangan Penelitian Pembelajaran Berbasis Inkuiri dalam Pendidikan Sains. Seminar Nasional II Himpunan Ikatan Sarjana dan Pemerhati Pendidikan IPA Indonesia. Bandung.

Sugiyono.(2015). Metode Penelitian Administrasi. Bandung: Alfabeta.

Susanne, Koerber, dkk. 2015. The Development of Scientific Thinking in Elementary School. Journalof Child Development. Vol. 86 (1): 327-336.

Undang-undang Republik Indonesia No 20. 2003. Sistem Pendidikan Nasional. Jakarta. Presiden Republik Indonesia. 
Unutkan, O. P. (2006). A Study of Pre-School Children's School Radiness Related to Scientific Thinking Skills. Journal of Distance Education-TODJE. 7(4): 78-85.
Wijayadi, Andri W. 2017. Pengaruh Strategi Pembelajaran dan Kemampuan Berpikir Ilmiah Terhadap Hasil Belajar Kimia. Jurnal Kimia dan Pendidikan. Vol.2 (2): 151160. 